\title{
DETERMINATION AND COMPARISON OF HYDRAULIC CONDUCTIVITY VALUES OF BED SILTS ALONG CHOTÁRNY CHANNEL USING GRAIN SIZE ANALYSIS
}

\author{
Renáta Dulovičová, Yvetta Velísková, Radoslav Schügerl
}

\begin{abstract}
This paper goes in for the evaluation of permeability of the bed silts located along the Chotárny channel at the Žitný ostrov (ŽO), Slovakia. The Chotárny channel is one of three main channels at the ŽO area - the flat lowland with channel network. Whole ŽO area has very low slope, so longitudinal slopes of all channels are negligible. This fact influences the formation of silts on the channel bottom. The bed silt permeability impacts water flow between surface water in the channel and surrounding groundwater in the scope of their interaction at this area. It is expressed by value of hydraulic conductivity, for our case, inasmuch as the bed silts are located in saturated zone under water level, by value of saturated hydraulic conductivity. This paper deals with disturbed samples extracted from the Chotárny channel and for that reason only the empirical formulas based on the grain size analysis were used for assessment of saturated hydraulic conductivity value. The disturbed samples were extracted in three different vertical parts of silt - top, middle and bottom part of silt layer and subsequently as mixed samples in each selected profile of the Chotárny channel. The selection of sampling place was made by thickness of bed silt in the measured profiles. The values of saturated hydraulic conductivity obtained from disturbed samples of bed silt $-K_{d}$ were calculated according to three empirical formulas: 1 . Bayer - Schweiger formula; 2. Špaček I formula and 3. Špaček II formula, firstly for samples from the single vertical parts of the silt layer (top, middle and bottom) and then for mixed samples. The valid values $K_{d}$ from single parts of the silt layers reached from $1.29 \times 10^{-08}$ to $1.19 \times 10^{-04} \mathrm{~m} \mathrm{~s}^{-1}$, the valid values $K_{d}$ from mixed samples reached from $1.38 \times 10^{-08}$ to $4.11 \times 10^{-06} \mathrm{~m} \mathrm{~s}^{-1}$. All values obtained using grain size analysis are only approximate, but the only possible ones in case of impossibility to take an undisturbed samples. According to results of comparison of $K_{d}$ from single vertical parts of silt layers and $K_{d}$ from mixed samples it is not possible to assess explicitly which values set of saturated hydraulic conductivity are more suitable to use in calculation or modelling. Next analysis of obtained datasets and comparison with the values of saturated hydraulic conductivity from undisturbed samples of bed silt will be necessary.
\end{abstract}

KEY WORDS: bed silts, disturbed samples, grain size analysis, silt permeability, hydraulic conductivity

\section{Introduction}

Žitný ostrov (ŽO) - a part of the Danube Lowland - was created by sediments transport from upper part of the Danube River (Fig. 1a). This area formed as a flat plain with only small differences in altitude. Its average slope is about $0.25 \%$ and it was one of the reasons for building channel network here. The longitudinal slopes of its channels are also very low. This fact had impact to production of bed silts on the channel bottom. The bed silts have been created by the surface runoff (or overland flow) and soil erosion from adjacent territory, as a results of manipulation with water-gates in the channel network and as a result of the decomposition of aquatic vegetation. The thickness and structure of bed silts influence the interaction between groundwater and water level in channel network. The rate of this interaction is important for agricultural production in this area, but also for regime of groundwater in this area. As important characteristics influencing this mutual interaction were determined the thickness and permeability of silts, which is often expressed by saturated hydraulic conductivity value. The channel network aggradation has been monitored and studied - many specialists dealt with it (Kosorin, 1997; Burger and Čelková, 2004; Mucha et al, 2006; Štekauerová et al., 2009; Baroková and Šoltész, 2014; Čelková, 2014; Kováčová, 2017; etc.). This paper shows some results of field measurements along the Chotárny channel - one of three main channels at the ŽO area (Fig. 1b).

\section{Material and methods}

Channel network at the ŽO area is created by several bigger channels - e.g. the channel Gabčíkovo-Topol'níky, the Chotárny channel, the Komárňanský channel, the channel Čalovo-Holiare-Kosihy, the channel Aszód -Čergov, the channel Čergov-Komárno, the channel Dudváh and by network of several smaller channels. Our research of channel network silting up has been concen- 


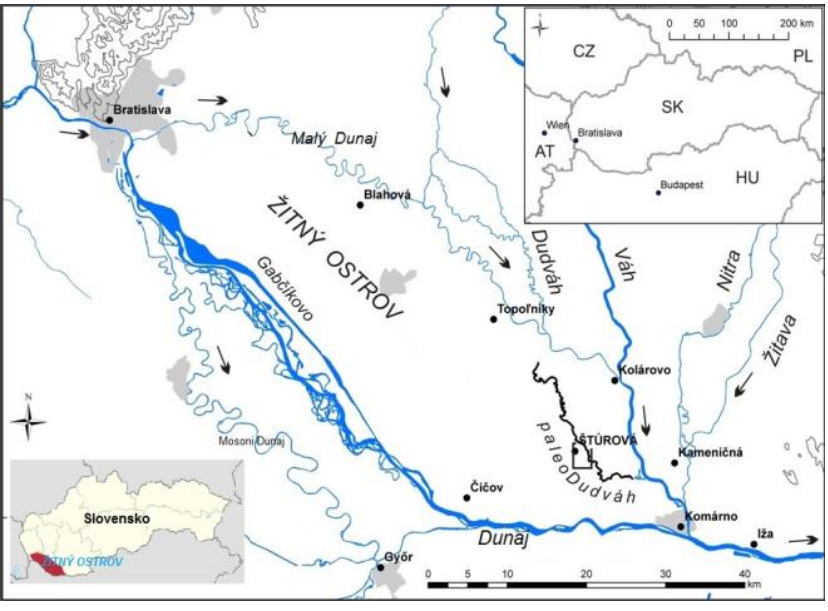

a)

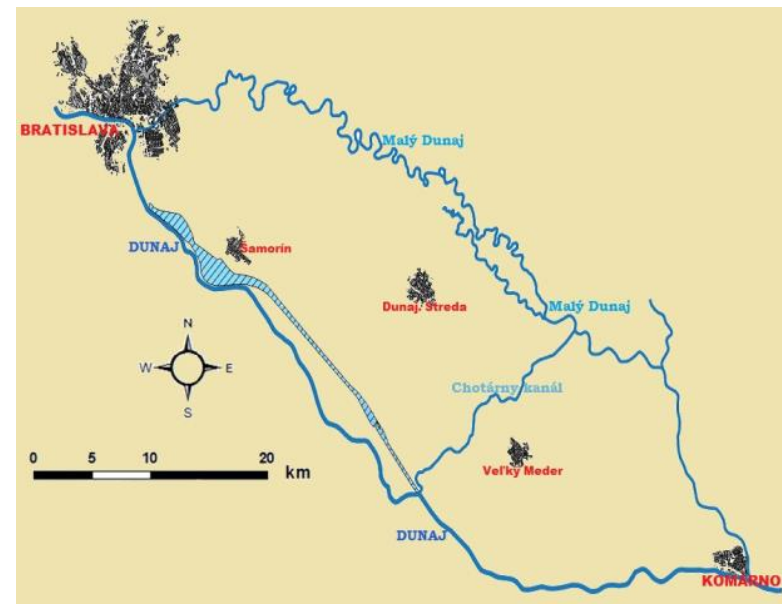

b)

Fig. 1. a) Localisation of the ŽO area (left), b) Location of the Chotárny channel at the ŽO area (right).

trated to three main channels of this network: the channel Gabčíkovo-Topol'níky, the Chotárny channel and the Komárňanský channel (Dulovičová, 2014; Dulovičová et al., 2016).

Chotárny channel is one from these three main channels of the ŽO channel network. Geometrical parameters of this channel observed during the measurements were: the channel length was approximately $27 \mathrm{~km}$, the channel width was in range 11-17.5 m, the channel depth run into maximal values up to $3.15 \mathrm{~m}$ (according to cross-section profiles location). The values of hydraulic conductivity in aquifers nearby this channel $K_{f s}$ were $0.40-3.4 \times 10^{-3}$ $\mathrm{m} \mathrm{s}^{-1}$ (Mišigová, 1988).

The measurements of bed silts thickness along the Chotárny channel were performed from the displaceable inflatable dinghy by simple drill hole. The distance of cross-section profiles along the channel varied between $1.0-1.5 \mathrm{~km}$. In all channel cross-section profiles there was measured the water depth and bed silts thickness with step 1.0-2.0 m along the channel width. The samples of channel bed silt were taken in these selected cross-section profiles where the largest channel bed silt thickness was noticed. The extraction of samples was done by sediment beeker sampler device. The silt sample was taken from each selected cross-section profile and then from each whole sample a part from top, middle and bottom layer was extracted. Finally, these separated samples were combined into a mixed sample (from all three layers). Next, the granularity analysis for each disturbed sample was performed, from which the value of saturated hydraulic conductivity was determined.

\section{Determination of saturated hydraulic conductivity of bed silts from granularity analysis}

Determination of hydraulic conductivity from disturbed samples of bed silts can be calculated by empirical formulas coming out from grain size analysis (Kutílek, 1978).

Several empirical formulas for determination of hydraulic conductivity from granularity exist, but it is possible to apply only a few of them because their limited validity. Therefore we used for our determination of saturated hydraulic conductivity of bed silts the relationships by Beyer-Schweiger and Špaček (Špaček, 1987). These relationships are functions of $\mathrm{d}_{10}$ - particle diameter in $10 \%$ of soil mass $(\mathrm{m})$ and $\mathrm{d}_{60}-$ particle diameter in $60 \%$ of soil mass [m]. Both of them were determined from granularity curves of all extracted samples of bed silts. The formula of Beyer-Schweiger, used for assessment of saturated hydraulic conductivity from disturbed samples of the Chotárny channel $-K_{d B S}\left[\mathrm{~m} \mathrm{~s}^{-1}\right]$, has a form:

$$
K_{d B S}=7.5 \times 10^{6} C\left(d_{10}\right)^{2}
$$

where

$C=1.5961 \times 10^{-3}\left(d_{60} / d_{10}\right)^{-0.20371}$;

$d_{10}$ - particle diameter in $10 \%$ of soil mass [m]; $d_{60}-$ particle diameter in $60 \%$ of soil mass $[\mathrm{m}]$;

and conditions of validity are:

$$
0.06 \leq d_{10} \leq 0.6 \quad \text { and } \quad 1 \leq \frac{d_{60}}{d_{10}} \leq 20
$$

Špaček formulas I, II $\left[\mathrm{m} \mathrm{d}^{-1}\right]$ for saturated hydraulic conductivity from disturbed samples of the Chotárny channel $K_{d}$ are as follows:

$$
\begin{aligned}
& K_{d \check{S I .}}=20.577\left(d_{10}\right)^{1.013}\left(\frac{0,5}{d_{60}-d_{10}}\right)^{0.059} \\
& K_{d \text { ŠI. }}=108.4386\left(d_{10}\right)^{0.8866}\left(d_{60}\right)^{0.7726}
\end{aligned}
$$


Dulovičová, $R$. et al.: Determination and comparison of hydraulic conductivity values of bed...

where

conditions of validity for application of eq.(2) are:

1. $d_{10}<0.01 \mathrm{~mm}$

or

2. $0.01 \leq d_{10}<0.13 \wedge d_{60}<0.0576+0.5765 d_{10}$

and conditions of validity for application of eq.(3) are:

1. $d_{10} \geq 0.13 \mathrm{~mm}$

or

2. $0.01 \leq d_{10}<0.13 \wedge d_{60}>0.0576+0.5765 d_{10}$

\section{Results and discussion}

Sometime it is not possible to take away undisturbed samples of bed silts or sediments and in the same moment it is necessary to know the rate of permeability of them. For this reason a way how to make it was searched. One way is the determination from granularity analysis. There are a lot of empirical relationships based on this analysis, but with a lot of limitations of validity, as well. As it was mentioned and described above, the value of saturated hydraulic conductivity as the indicator of channel bed silt permeability was determined for disturbed samples by the Beyer-Schweiger and two Špaček's formulas. Each of them determines this variable quantity as a function of $d_{10}$ and $d_{60}$.Conditions of validity for application of these formulas also depends on value of $d_{10}$ and $d_{60}$ (Šurda et al., 2013). The both values were determined separately for the top, middle and bottom part of extracted samples and then for mixed samples from measured sample points along the Chotárny channel. The obtained and determined values of saturated hydraulic conductivity of disturbed samples $K_{d}$ extracted from top, middle and bottom layer of bed silt are summed in Table 1 . The valid values of channel bed silt saturated hydraulic conductivity from single parts of the silt layers reached from $1.29 \times 10^{-08}$ to $1.19 \times 10^{-04} \mathrm{~m} \mathrm{~s}^{-1}$. The graphical interpretation of results is in Fig. 2.

The values of saturated hydraulic conductivity of disturbed samples $K_{d}$ extracted from mixed samples of bed silt along the Chotárny channel are summed in Table 2. The valid values of channel bed silt saturated hydraulic conductivity from mixed samples reached from $1.38 \times 10^{-08}$ to $4.11 \times 10^{-06} \mathrm{~m} \mathrm{~s}^{-1}$. The graphical interpretation of these results is in Fig. 3.

Table 1. Chotárny channel - valid values of $K_{d}$ from single parts of the silt layers in 2018

\begin{tabular}{|c|c|c|c|c|}
\hline Channel & Chotárny & & & \\
\hline \multirow{2}{*}{$\begin{array}{c}\text { Channel stationing } \\
{[\mathrm{rkm}]}\end{array}$} & \multirow[t]{2}{*}{ Silt layer } & \multicolumn{3}{|c|}{$\begin{array}{ll}K_{d} & {\left[\mathrm{~m} \mathrm{~s}^{-1}\right]}\end{array}$} \\
\hline & & Bayer-Schweiger & Špaček I. & Špaček II. \\
\hline \multirow{3}{*}{1.2} & top & $3.81 \times 10^{-08}$ & $6.03 \times 10^{-07}$ & - \\
\hline & middle & - & - & $1.02 \times 10^{-06}$ \\
\hline & bottom & - & $5.06 \times 10^{-07}$ & - \\
\hline \multirow{3}{*}{6.0} & top & $4.13 \times 10^{-06}$ & - & $2.62 \times 10^{-05}$ \\
\hline & middle & $1.80 \times 10^{-08}$ & $4.23 \times 10^{-07}$ & - \\
\hline & bottom & $6.30 \times 10^{-05}$ & - & $1.19 \times 10^{-04}$ \\
\hline \multirow{3}{*}{8.6} & top & - & $7.64 \times 10^{-07}$ & $1.69 \times 10^{-06}$ \\
\hline & middle & - & - & $2.04 \times 10^{-05}$ \\
\hline & bottom & $1.68 \times 10^{-07}$ & $1.24 \times 10^{-06}$ & $1.70 \times 10^{-06}$ \\
\hline \multirow{3}{*}{16.3} & top & $1.99 \times 10^{-08}$ & $4.45 \times 10^{-07}$ & - \\
\hline & middle & - & $5.05 \times 10^{-07}$ & - \\
\hline & bottom & $3.32 \times 10^{-08}$ & $5.69 \times 10^{-07}$ & - \\
\hline \multirow{3}{*}{18.0} & top & $2.15 \times 10^{-08}$ & $4.61 \times 10^{-07}$ & - \\
\hline & middle & - & $4.11 \times 10^{-07}$ & - \\
\hline & bottom & $1.59 \times 10^{-08}$ & $3.99 \times 10^{-07}$ & - \\
\hline \multirow{3}{*}{20.0} & top & $1.97 \times 10^{-08}$ & $4.44 \times 10^{-07}$ & - \\
\hline & middle & $1.29 \times 10^{-08}$ & $3.66 \times 10^{-07}$ & - \\
\hline & bottom & $1.37 \times 10^{-08}$ & $3.72 \times 10^{-07}$ & - \\
\hline \multirow{3}{*}{24.6} & top & - & $5.50 \times 10^{-07}$ & $6.29 \times 10^{-07}$ \\
\hline & middle & - & $1.66 \times 10^{-06}$ & $4.28 \times 10^{-06}$ \\
\hline & bottom & - & $5.16 \times 10^{-07}$ & $2.61 \times 10^{-06}$ \\
\hline \multirow{3}{*}{25.5} & top & $1.06 \times 10^{-07}$ & $9.95 \times 10^{-07}$ & $1.27 \times 10^{-06}$ \\
\hline & middle & - & $6.60 \times 10^{-07}$ & $1.03 \times 10^{-06}$ \\
\hline & bottom & - & - & $1.29 \times 10^{-05}$ \\
\hline
\end{tabular}


Table 2. Chotárny channel - valid values of $K_{d}$ from mixed samples of the silt in year 2018

\begin{tabular}{|c|c|c|c|c|}
\hline Channel & Chotárny & & & \\
\hline \multirow{2}{*}{$\begin{array}{c}\text { Channel stationing } \\
{[\mathrm{rkm}]}\end{array}$} & \multirow[t]{2}{*}{ Silt layer } & \multicolumn{3}{|c|}{$K_{d}\left[\mathrm{~m} \mathrm{~s}^{-1}\right]$} \\
\hline & & Bayer-Schweiger & Špaček I. & Špaček II. \\
\hline $1.2-1.3$ & $\begin{array}{c}\text { mixed sample } \\
\text { (top }+ \text { middle }+ \text { bottom })\end{array}$ & $1.89 \times 10^{-08}$ & $4.39 \times 10^{-07}$ & - \\
\hline 6.0 & $\begin{array}{c}\text { mixed sample } \\
\text { (top }+ \text { middle }+ \text { bottom })\end{array}$ & - & $4.65 \times 10^{-07}$ & $6.90 \times 10^{-07}$ \\
\hline 8.7 & $\begin{array}{c}\text { mixed sample } \\
\text { (top }+ \text { middle }+ \text { bottom })\end{array}$ & - & $6.44 \times 10^{-07}$ & $3.88 \times 10^{-06}$ \\
\hline 16.3 & $\begin{array}{c}\text { mixed sample } \\
\text { (top }+ \text { middle }+ \text { bottom })\end{array}$ & $4.32 \times 10^{-08}$ & $6.45 \times 10^{-07}$ & - \\
\hline 18.0 & $\begin{array}{c}\text { mixed sample } \\
\text { (top }+ \text { middle }+ \text { bottom })\end{array}$ & - & $4.34 \times 10^{-07}$ & - \\
\hline 20.0 & $\begin{array}{c}\text { mixed sample } \\
\text { (top }+ \text { middle }+ \text { bottom })\end{array}$ & $1.38 \times 10^{-08}$ & $3.73 \times 10^{-07}$ & - \\
\hline 24.6 & $\begin{array}{c}\text { mixed sample } \\
(\text { top }+ \text { middle }+ \text { bottom })\end{array}$ & - & $1.03 \times 10^{-06}$ & $4.11 \times 10^{-06}$ \\
\hline 25.5 & $\begin{array}{c}\text { mixed sample } \\
\text { (top }+ \text { middle }+ \text { bottom })\end{array}$ & - & $9.54 \times 10^{-07}$ & $2.17 \times 10^{-06}$ \\
\hline
\end{tabular}

- unkept conditions of validity for aplication of Beyer-Schweiger's and Špaček's formulas

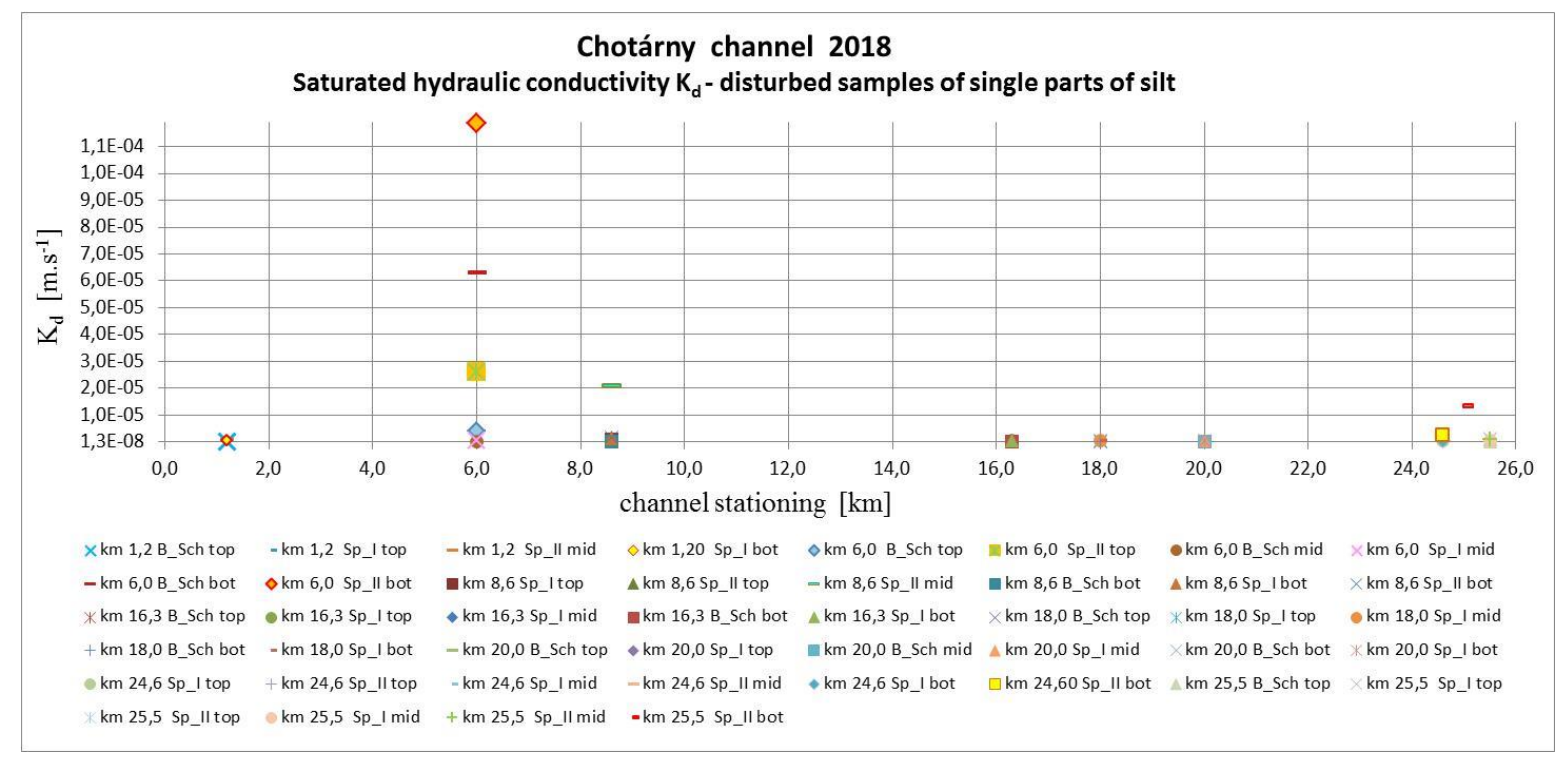

Fig. 2. The graphical presentation of $K_{d}$ for disturbed samples from single parts of silt layer.

Comparing $K_{d}$ value of single parts of silt layers extracted along the Chotárny channel, the various ranges among top, middle and bottom layer were identified. In rkm 1.2 the valid values of saturated hydraulic conductivity $K_{d}$ in single layers were from $10^{-08}$ to $10^{-06} \mathrm{~m} \mathrm{~s}^{-1}$, withal the value $10^{-7} \mathrm{~m} \mathrm{~s}^{-1}$ predominated. In rkm 6.0 was larger range of values $K_{d}$ - from $10^{-08}$ to $10^{-04} \mathrm{~m} \mathrm{~s}^{-1}$, in rkm 8.6 the values of $K_{d}$ were from $10^{-07}$ to $10^{-05} \mathrm{~m} \mathrm{~s}^{-1}$. From rkm 16.3 to $\mathrm{rkm} 20.0$ the values of $K_{d}$ changed from $10^{-08}$ to $10^{-07}$ $\mathrm{m} \mathrm{s}^{-1}$, withal the value $10^{-7} \mathrm{~m} \mathrm{~s}^{-1}$ (calculated by Špaček I) predominated. In $\mathrm{km} 24.6$ was range of $K_{d}$ only from $10^{-07}$ to $10^{-06} \mathrm{~m} \mathrm{~s}^{-1}$ (by Špaček I, II). In rkm 25.5 the values $K_{d}$ varied from $10^{-07}$ to $10^{-05} \mathrm{~m} \mathrm{~s}^{-1}$.

In the case of mixed disturbed samples of bed silt extracted along the Chotárny channel, the valid values $K_{d}$ ranged from $10^{-08}$ to $10^{-06} \mathrm{~m} \mathrm{~s}^{-1}$. In rkm $1.2-1.3$ the valid values $K_{d}$, calculated by Bayer-Schweiger (Eq.1) and Špaček I (Eq. 2) formulas, varied only from $10^{-08}$ to $10^{-07}$ $\mathrm{m} \mathrm{s}^{-1}$. From rkm 6.0 to rkm 8.7 the valid values $K_{d}$ ranged from $10^{-07}$ to $10^{-06} \mathrm{~m} \mathrm{~s}^{-1}$, the value $10^{-7} \mathrm{~m} \mathrm{~s}^{-1}$ predominated 


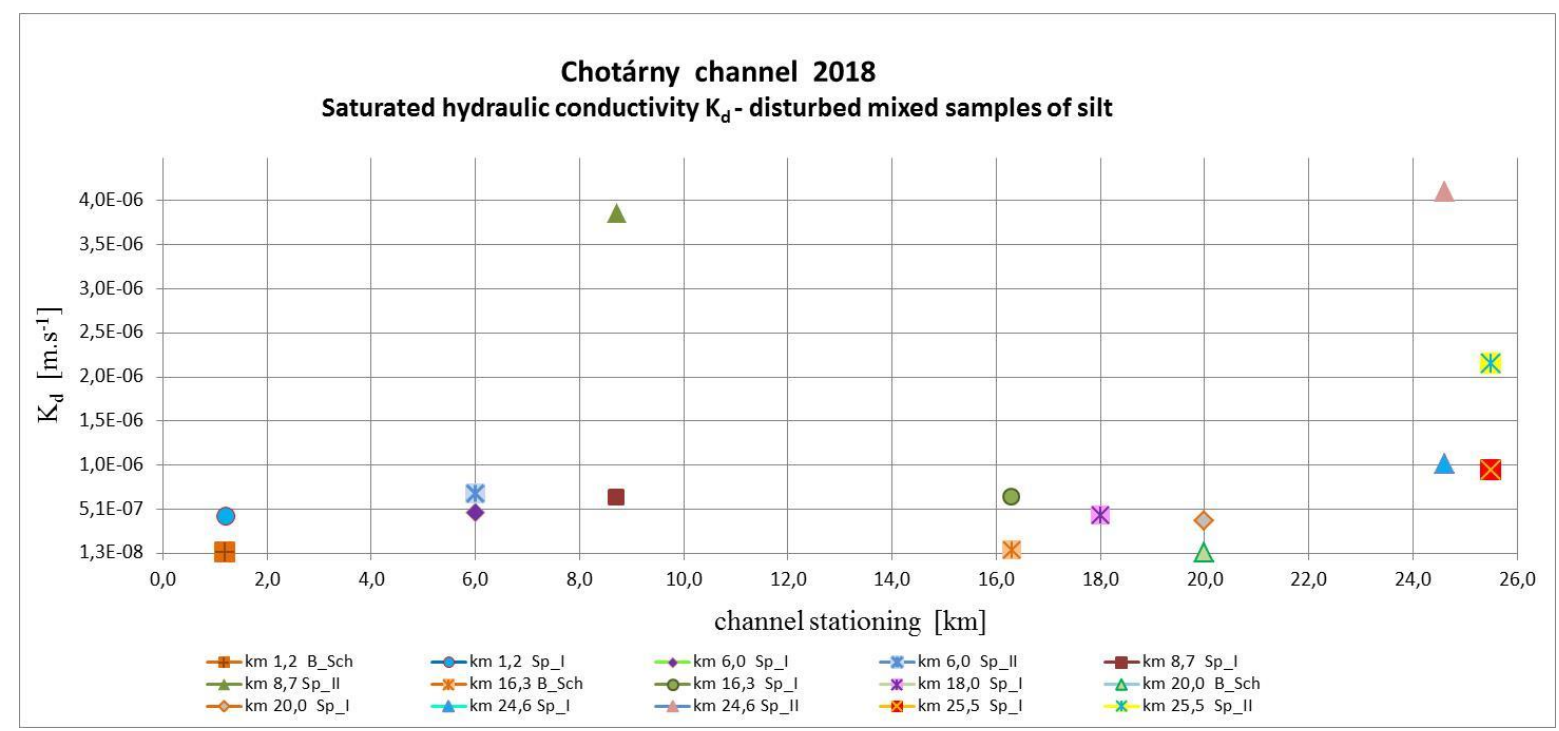

Fig. 3. The graphical presentation of $K_{d}$ for mixed disturbed samples of silt.

(calculated by Špaček I (Eq. 2) and Špaček II (Eq.3)). From rkm 16.3 to $\mathrm{rkm} 20.0$ the values of $K_{d}$ varied from $10^{-08}$ to $10^{-07} \mathrm{~m} \mathrm{~s}^{-1}$, with dominance $10^{-07} \mathrm{~m} \mathrm{~s}^{-1}$ (by Špaček I (Eq. 2)). In rkm 24.6 and 25.5 were the valid values $K_{d}$ in range only from $10^{-07}$ to $10^{-06} \mathrm{~m} \mathrm{~s}^{-1}$, where the value $10^{-06} \mathrm{~m} \mathrm{~s}^{-1}$ predominated.

Comparing of the values $K_{d}$, extracted from single parts of silt layers and from mixed samples of silt, some small differences were detected. The values $K_{d}$ according Bayer-Schweiger formula (Eq. 1) were mostly $10^{-08}$, but the possibility to apply this formula for mixed samples was only in $\mathrm{rkm} \mathrm{1.2,16.3} \mathrm{and} \mathrm{20.0.} \mathrm{The} \mathrm{values} K_{d}$ according Špaček I formula (Eq. 2) were mostly $10^{-07}$ $\mathrm{m} \mathrm{s}^{-1}$ and its applicability was nearly in the same extent, except $\mathrm{rkm} 8.6$ and $\mathrm{rkm} 24.6$ for single silt layers, and rkm 24.6 for mixed samples of silt (here the $K_{d}$ values were $10^{-06} \mathrm{~m} \mathrm{~s}^{-1}$ ). The values $K_{d}$ according Špaček II formula (Eq. 3) varied from $10^{-07}$ to $10^{-04} \mathrm{~m} \mathrm{~s}^{-1}$, mostly $10^{-06}$ $\mathrm{m} \mathrm{s}^{-1}$. The application of Eq. 3 was not valid from rkm 16.3 to $\mathrm{rkm} 20.0$ for both cases (single layers of silt and mixed silt samples). At comparison of the values of saturated hydraulic conductivity $K_{d}$ of bed silts extracted from single silt layers and $K_{d}$ from mixed silt samples are evident only very small differences or variation.

Comparing of obtained range of values of saturated hydraulic conductivity and values of this characteristic for typical fresh groundwater conditions with using standard values of viscosity and specific gravity for water at $20{ }^{\circ} \mathrm{C}$ and $1 \mathrm{~atm}$, the values of $K_{d}$ determined for the Chotárny channel bed silts represent a semi-pervious to impervious conditions of bed sediments (Bear, 1972).

\section{Conclusion}

This paper is aimed to the evaluation of bed silt permeability along the Chotárny channel on base of field measurements performed during the year 2018 at the ŽO area. The thickness of bed silt and the permeability of channel bed silt fundamentally influence and determine the rate of mutual interaction between surface water in the Chotárny channel and groundwater in its surroundings. For this reason, it is important to research and monitor continuously the state of channel bed aggradation and to know the permeability of bed silt, expressed by its value of saturated hydraulic conductivity.

The values of saturated hydraulic conductivity of bed silt along the Chotárny channel were determined according to three formulas applicable for disturbed samples of bed silts, which are based on granularity analysis of samples. The resultant values are presented in Table 1 and Table 2. The valid values of saturated hydraulic conductivity of the channel bed silt for single parts of bed silt layers reached from $1.29 \times 10^{-08}$ to $1.19 \times 10^{-04} \mathrm{~m} \mathrm{~s}^{-1}$, the valid values of channel bed silt saturated hydraulic conductivity from mixed samples reached from $1.38 \times 10^{-08}$ to $4.11 \times 10^{-06} \mathrm{~m} \mathrm{~s}^{-1}$. These values mean semi-pervious to impervious environment.

Comparison of values of saturated hydraulic conductivity between top, middle and bottom parts of bed silt layers did not appear significantly marked differences. The value of decimal order $10^{-07}$ prevailed in all layers. The values of saturated hydraulic conductivity of mixed disturbed samples of bed silt were also analysed and the value $10^{-07}$ prevailed again. Comparison of the values of saturated hydraulic conductivity $K_{d}$ from single parts of silt layers and $K_{d}$ from mixed silt samples showed only small differences. On the base of analysis of these results it can be taken a note that it is not possible to assess explicitly the reliability of saturated hydraulic conductivity value set by this way. In the next level of our research is needful to compare these results with the values obtained from undisturbed samples of bed silts determined by the laboratory falling head method. However, all obtained information about bed silt thicknesses supplemented by values of saturated hydraulic 
conductivity of bed silt will be usable for numerical simulation models and simultaneously they represent rare information for any future way of groundwater level regulation in surroundings of the Chotárny channel or other channels at the ŽO area.

\section{Acknowledgement}

This work is support by the contract VEGA-02/0025/19 and APVV-14-0735.

\section{References}

Baroková, D., Šoltész, A. (2014): Analysis of surface and groundwater interaction in the Danube river branch system., SGEM Conference Proceedings, 14th SGEM Geo-Conference on Water Resources. Forest, Marine and Ocean Ecosystems, Vol. I., www.sgem.org, ISBN 978619-7105-13-1 / ISSN 1314-2704, 51-58.

Bear, J. (1972): Dynamics of Fluids in Porous Media. Dover Publications, ISBN 0-486-65675-6.

Burger, F. Čelková, A. (2004): Simulation of aquifer feeding processes during dry period. Acta Hydrologica Slovaca, Vol. 5, No.2, 348-357. (in Slovak)

Čelková, A. (2014): The influence of groundwater on soil salinization in the alluvium in the left bank side of Danube river between Komárno and Štúrovo. Acta Hydrologica Slovaca, Vol. 15, No. 2, 413-423 (in Slovak)

Dulovičová, R. (2014): Aggradation changes at Komárňanský channel during period 1993-2013. Acta Hydrologica Slovaca, Vol. 15, Temat. No., 103-111 (in Slovak)
Dulovičová, R., Velísková, Y., Schügerl, R. (2016): Hydraulic conductivity of silts in Chotárny channel at Žitný ostrov. Acta Hydrol. Slovaca, Vol. 17, No. 2, 149-156 (in Slovak)

Kosorin, K. (1997): Spatial groundwater dynamics of the Rye Island aquifer. J. Hydrol. Hydromech., Vol. 45, 348-364.

Kováčová, V. (2017): Trends of nitrate ions content in Žitný Ostrov channel network. Acta Hydrologica Slovaca, Vol. 18, No. 1, 57-67 (in Slovak)

Kutílek, M. (1978): Vodohospodářská pedologie, Alfa Bratislava, SNTL 04-721-78, 296 p., (in Czech)

Mišigová, I., (1988): Methods of regional assessment of hydraulic properties of the rocks on the Žitný Ostrov. Report IHH SAS, (in Slovak)

Mucha, I., Banský L., Hlavatý Z., Rodák D (2006): Impact of riverbed clogging colmatation on ground water, Riverbank Filtration Hydrology: Impacts on System Capacity and Water Quality. NATO Science Series: IV. Earth and Environmental Sciences - Vol. 60, Springer, 43-72. (printed in the Netherlands)

Špaček, J. (1987): Determination of filtration coefficient from total grain-size curves. J. Meliorace, Vol. 23, No.1, 1-13 (in Czech)

Šurda, P., Štekauerová, V., Nagy, V. (2013): Variability of the saturated hydraulic conductivity of the individual soil types in the area of the Hron catchment. Nővénytermelés, Vol. 62, supplement, 323-326.

Štekauerová, V., Nagy V., Šútor J., Milics G., Neményi M. (2009): Influence of groundwater level on soil water regime of Žitný ostrov. In V. Növénytermesztési Tudományos Nap - Növénytermesztés: Gazdálkodás Klímaváltozás - Társadalom, Akadémiai Kiadó, Budapest, 197-200

Ing. Renáta Dulovičová ("corresponding author, e-mail: dulovicova@uh.savba.sk)

Ing. Yvetta Velísková, PhD.

Mgr. Radoslav Schügerl, PhD.

Institute of Hydrology SAS

Dúbravská cesta 9

84104 Bratislava

Slovak Republic 